\title{
Educating Rita: The Muted Woman Raises Her Voice
}

\author{
Seval Arslan, PhD. Cand. \\ Lecturer, Department of English Language and Literature, Fatih University, Istanbul \\ sevalsarslan@hotmail.com
}

\section{Doi:10.5901/jesr.2015.v5n1s1p111}

\begin{abstract}
For centuries, women have been excluded from the literary canon which has been under the dominance of male authors. The socio-political and domestic spheres of life have been divided according to the Cartesian dualism between the mind and body which is based on the already determined characteristics of man and woman by the patriarchal order. Woman has been doomed to the domestic sphere with certain responsibilities as a wife and mother; thus, she has been deprived of an active participation in the social sphere of life. If woman stays at home, she is drowned in a lack of a self, however, if she wants to pave her way towards an intellectual life, she will have to obtain a masculine position which, again, absorbs her female identity. In Educating Rita, Willy Russell narrates the story of Rita, a working class woman, who is devoid of a self and tries to overcome the difficulties life brings to her due to her social status and her sex. This paper is going to discuss Rita's personal struggle to pass beyond these restrictions via reading and writing in order to obtain her own thinking and critical self that gives her the right to choose rather than to be chosen. Thus, overcoming the distinction between the reproductive body and contemplative mind, woman is able to assert her sophisticated self through active participation in the intellectual life outside the domestic sphere. Consequently, the muted woman is able to raise her voice by claiming her own independent identity.
\end{abstract}

Keywords: Woman's identity, reading theory, woman's writing.

In What Is a Woman? Toril Moi discusses that science and philosophy are based on the Cartesian mind/body dualism. The patriarchal worldview structures society on the separation of the mind and body from a sexist perspective. Within this structure, man represents the mind while woman is pre-destined to be the symbol of the body. The socio-political and domestic spheres of life are divided according to this dualism which is based on the determined characteristics of man and woman by the masculine order. Thus woman is believed to be fit to be a good wife, mother and housekeeper while man's way is paved for a more social, political and philosophical life in which he can use his creative intellect. From this point of view, woman's tasks are the ones that do not necessitate a creative-thinking process such as bearing and rearing babies, cooking and cleaning the house while man's duties are more social and enable him to be part of the social structure. Moi (1999) emphasizes that "the rational, active, masculine intellect operates on the passive, objectified, feminized body" (p. 348). Hence woman is doomed to a submissive state as the object in this subject/object relationship between the sexes.

As an ultimate result of this dualistic approach, science, philosophy and literature have always been under the dominance of man; therefore, if woman is ever eager to be part of this system in order to include herself in philosophy and literature, she is supposed to have a masculine status ignoring her womanhood. Otherwise, Moi (1999) asserts, she has to obey the sexist structure that destines women to become the irrational and thoughtless bodies of the rational and creative minds (p. 348). The problem woman faces within this patriarchal structure is that she is left without a true self, and this causes her to forget about her existence and identity; eventually she becomes part of the male world as an object, and she ends up being both the tool and victim of patriarchy. If she stays at home as expected from her, she is drowned in the lack of a self, however, on the other hand, if she wants to pave her way towards a more social and philosophical life, she will have to obtain a masculine position which, again, absorbs her identity. In Educating Rita, Willy Russell narrates the story of Rita, a working class woman, who is devoid of a self and tries to overcome the difficulties life brings to her due to her social status and her sex. This paper is going to discuss Rita's personal struggle to pass beyond these restrictions via reading and writing in order to obtain her own thinking and critical self that gives her the right to choose rather than to be chosen.

For centuries, women have been excluded from the literary canon which has been under the dominance of male authors. This male dominance in the literary and philosophical domains has been caused by the Cartesian dualism between the mind and body as discussed above. Because of their procreative status as mothers, women have been regarded as pure wombs, and they have been devoid of other creative activities like thinking and writing that were 
attributed to the male genius with his creative intellectuality. Sandra M. Gilbert and Susan Gubar (2000) begin their discussion about the male-dominated philosophy and literature in The Madwoman in the Attic with the following question: "Is a pen a metaphorical penis?" (p. 3). Literature and philosophy have always been under such an influence of the patriarchal structure that women have been almost completely alienated from the process of creative thinking and writing since they have been supposed to be the irrational and passive side of the dual structure. Gilbert and Gubar (2000) continue their debate about this comparison between the pen and penis questioning the position of woman within this structure:

If the pen is a metaphorical penis, with what organ can females generate texts? The question may seem frivolous, but both the patriarchal etiology that defines a solitary Father God as the only creator of all things, and the male metaphors of literary creation that depend upon such an etiology, have long "confused" literary women, readers and writers alike. For what if such a proudly masculine cosmic Author is the sole legitimate model for all earthly authors? Or worse, what if the male generative power is not just the only legitimate power but the only power there is? That literary theoreticians from Aristotle to Hopkins seemed to believe this was so no doubt prevented many women from ever "attempting the pen" and caused enormous anxiety in generations of those women who are "presumptuous" enough to dare such an attempt. (p. 7)

As stated above, if the pen is a metaphorical penis, there is no way left for a woman to be included in this patriarchal literary canon since she clearly lacks the penis which prevents her from raising her voice in the masculine order of literature and philosophy. Beginning with God the Father as the creator of all things in the world, man is attributed the quality of intellectual creativity while woman is left out as the passive object on which the male intellect operates. Since woman is doomed to stay as the mere womb which is a tool to help male procreation, man has been regarded as the chief being within the philosophical thinking and critical writing process. Since the ancient times of the primary philosophers like Aristotle and Plato, men have been considered to be the only legitimate generative power, and this patriarchal view of philosophy and literature has determined the restricted position of woman.

The exclusion of woman from the literary and philosophical domains has eventually resulted in the belief that the women who attempt to include themselves in this creative process are actually "presumptuous" since they betray their nature doing so. At this point, arguing about the so-called female nature that is betrayed by the women who try to exceed their boundaries surrounding their domestic lives, Gilbert and Gubar (2000) assert that these women are not only called to be "intrusive" and "presumptuous", but they are also completely "unredeemable" because there is a big mistake in trying to overcome the boundaries drawn by nature (p. 8). However, it is vitally important to emphasize that these boundaries that the woman, who is interested in philosophical thinking, is considered to cross betraying her nature are not determined by nature itself but only by the patriarchal system that situates man as the primary intellectual and creative subject.

This is actually what Rita tries to do in Willy Russell's Educating Rita. As a working class woman, Rita struggles very hard in order to cross the boundaries that enclose her within a structure that is chosen for her. All her attempt is to become the one who is capable of choosing for herself avoiding the patriarchal power that determines her fate as a true wife and mother. The way she chooses to liberate herself goes through studying, and she tries to learn reading and writing critically. She is enrolled in the Open University, and she also takes courses from an English professor Frank. The play includes the relationship between Rita and Frank which eventually affects not only Rita's but also Frank's perspective for reading and writing critically; as a result, they end up teaching each other and switching their roles. In the early beginning of the play, Frank is on the stage talking to his girlfriend on the phone. While he is talking about Rita, his sexist prejudices appear clearly:

Yes?... Of course I'm still here... Because I've got this Open University woman coming, haven't I?... Yes, I probably shall go to the pub afterwards, I shall need to wash away the memory of some silly woman's attempts to get into the mind of Henry James or whoever it is we're supposed to study on this course... (Russell, 2001, p. 3)

Frank's first ideas about Rita who studies at the Open University show man's reaction to woman's attempts to participate in the literary sphere. Mocking Rita as a prototype of all women who try to learn critical thinking and reading, Frank makes the prejudiced male opinion clear. According to this perspective, women are not capable of critical reading and thinking since they can easily be over-identified with the author or the characters in the story. In Theories of Reading Karin Littau (2006) discusses the problem of over-identification especially for women readers who are believed to end up devouring stories by reading fleetingly. However, Littau asserts that over-identification is not the only problem that makes reading fiction dangerous. She asserts that another important aspect of this danger is the belief that "unlike serious reading which 'lifts the reader from sensation to intellect', the novel actually does the opposite" (p. 65). Since woman has always been made synonymous with sensation, her over-identification and absorption in novel reading is 
explained as her lack of capability for critical and objective reading.

On the other hand, focusing on the comparison between the lack of a penis and the female exclusion from philosophy, Toril Moi (1999) asserts that:

First, woman is perceived as lacking the phallus. According to the patriarchal imagination, what a woman needs is a man, not philosophy. If a woman declares that she too feels the philosophical lack, her desire for knowledge can only be a compensation for her primary sexual frustration. On this logic, then, the thinking woman necessarily becomes synonymous with the bluestocking, the frustrated spinster of patriarchal ideology: the female lack is never truly a philosophical lack. In other words, the woman is always suspected of not being able to think simply because she is taken to suffer from the wrong lack. (p. 356)

Based on the sexual discrimination that is structured on man's physical and sexual power deriving from the phallus, Toril Moi (1999) argues about the patriarchal belief that the true lack of woman is not philosophical thinking but the male sexual organ which gives him autonomy. Thus, what woman needs to fulfil the absence of the phallus is not philosophy but man himself. This analysis of woman's lack stems from the dichotomy within the patriarchal structure that controls the sexist approach based on the certain gender roles attributed to both sexes. That is why, Moi asserts, woman's attempt to fulfil herself philosophically is actually considered to be seeking for fulfilment for a wrong lack because the true lack that she suffers from can be fulfilled only through submission to male sexual and intellectual power. Thus, woman's desire for knowledge is regarded as a wrong way of compensation for the female lack of the generative phallus and her ultimate sexual frustration from the masculine perspective (p. 356). As a result of this active male physical and sexual power, man has claimed himself as the authoritative voice in the socio-political, economic and philosophical life subordinating woman to a passive status in which she is absolutely objectified, and her voice is silenced within the domestic sphere. As clearly seen in the example of Rita, woman is not considered to be capable of philosophical and critical reading, and her wish to pave her way into a more literary life forces her to be part of this maledominated structure. Thus the most important aspect of this process for Rita is not only to become an acknowledged person but also to be a free one to choose for herself rather than being a dependent woman for whom others choose. As discussed above, woman's attempts to be included in this sphere ultimately results in detaching her from her identity since this literary canon is dominated by the masculine power. As a result, woman is forced to choose between her womanhood and her literacy in an unjust way. However, for Rita this process of being taught by Frank becomes a way for her to seek her independent choice without the male authority.

When Rita meets Frank for the first time, this is actually not the beginning of her reading process. While she introduces herself as Rita, Frank who checks her admission papers realizes that her name is written as Mrs. S. White. Although her actual name is Susan, she renames herself after Rita Mae Brown, the author of Rubyfruit Jungle which is one of her favourite novels in the beginning. In a sense, she identifies herself with this author she likes most, and this shows her wish to become a reader and writer at the same time.

In his arguments about woman's tendency for identification David Bleich (1986) indicates that, woman tends to identify more with the author of the story or with the characters in it. For him, the reason for woman's tendency for identification stems from "the condition of less otherness" (p. 264). Bleich points out that the difference between man and woman in regard to this topic stems from their different responses to otherness and objectivity. According to him both men and women attempt to objectify things, however, this act of objectification does not seem to be an immediately necessary one for women as it is for men. David Bleich (1986) tries to explain this notion of "less otherness" biologically focusing on the fact that although both man and woman are born of women, man needs to detach himself from his mother to find his own identity. On the other hand, as woman tries to detach herself from her mother to discover her self, she will have to turn back to her mother while trying to acquire her gender based identity. This case is completely different for man who gets more and more detached from his mother as he continues to shape his gender based identity (p. 265). Eventually, the result is that man feels the urgent need to objectify his readings while woman lacks this urgency, and she is more easily absorbed in the fictional lives of characters as well as the creators of that fictional life. Thus Rita's naming herself after her favourite fiction writer shows us her struggle to find her liberation out of the prison she is entrapped in both as a working class member and a woman in the patriarchal order.

In the first conversation Rita and Frank have, Rita talks about her previous readings, and all the names she utters are the ones Frank is not even familiar with. This shows us her social and literary background; she comes from the working class environment, and her taste in the literary field is actually shaped by junk literature. The first time when they begin teaching each other in the opposite ways is when she gives Rubyfruit Jungle to Frank to read while she borrows Howards End from him. As she takes Howards End to read, Rita says she will post it to him if she decides to drop the course because she "might decide it was a soft idea" (Russell, 2001, p. 8). At this point she still seems to be in conflict 
with what she is struggling for since it is obviously a betrayal for her so-called nature both in her working class environment and in the overall patriarchal structure. The problem for woman in this masculine system is that her voice has been silenced by the male-dominated philosophical canon, and eventually she is doomed to her so-called feminine nature to deal with the female sphere of life. This position of woman in the patriarchal society has affected her existence as a reader and writer at the same time.

Thus arguing about reader's construction of meaning and the effects of gender on comprehension, Mary Crawford and Roger Chaffin (1986) focus on women as a muted group and state that,

The theory of muted groups was developed to describe situations in which groups of people exist in asymmetrical power relationships. The theory proposes that language and the norms for its use are controlled by the dominant group. Members of the muted group are disadvantaged in articulating their experience, since the language they must use is derived largely from the perceptions of the dominant group... In order to be heard, muted group members must learn the dominant idiom and attempt to articulate within it, even though this attempt will inevitably lead to some loss of meaning. (p. 21)

Due to the male dominance in literature and philosophy, language is also under the control of the patriarchal point of view which excludes women from the canon. As a result, women have been subordinated as the muted group while men have been included in the dominant group that controls language. Extremely surrounded by the patriarchal dominance, the muted group of women has been forced to identify with this language in order to tell about women's experiences. However, since this language serves the dominant group, the muted group always lacks the proper way of expression for its own experiences. As Crawford and Chaffin (1986) also point out, the muted group is supposed to learn the dominant group's idiom in order to be heard within this structure, and this will eventually cause women to lose their intended meaning within the male idiom (p. 21).

Since man and woman have different backgrounds that are shaped according to their sex, their reading and critical thinking will also be affected deeply by the contexts they find themselves in the patriarchal society. As a direct consequence of the masculine language in the philosophical and literary canon, woman has to face her loss of self, and her attempts to find herself in the masculine language dooms her to a contradictive status between her real female identity and the masculine representation of her femininity. Hence, man's authority in philosophy has silenced woman's voice to be lost in the male sovereignty. The women who have been interested in critical thinking and writing have been doomed to the masculine dominance both in literature and language which has resulted in their contradictory position between a real female self and the male representation of the female gender.

Focusing on the problem of the representation of woman in the male-dominated language, Judith Butler (2006) discusses that:

For feminist theory, the development of a language that fully or adequately represents women has seemed necessary to foster the political visibility of women. This has seemed obviously important considering the pervasive cultural condition in which women's lives were either misrepresented or not represented at all. (p. 2)

As Judith Butler argues, the development of a language that is not based on the patriarchal power and its representation of woman has been one of the most important points of the feminist movement so far. Since the masculine language either misrepresents or does not represent the circumstances women find themselves in at all, woman has been doomed to an absolute loss of self, and this loss subordinates her to the passive and irrational status she is entrapped in. Therefore, the development of a language free from the masculine domination is necessary to pave woman's way into a creative and philosophical sphere. However, it is also necessary to keep in mind that the only way to develop such a language goes through getting familiar with the male dominated literary canon so that woman can face man's representation of woman and then assert her own representation of herself. Thus, woman should betray her socalled nature that is determined by the patriarchal system in order to cross the boundaries that surround her within the limited space she is allowed in. For Rita, this is also the first step she needs to take in order to educate herself. She needs to be familiar with the literary canon that is dominated by the male authors who also control the language that is used. As Patrocinio P. Schweickart (1986) asserts, "The feminist inquiry into the activity of reading begins with the realization that the literary canon is androcentric, and that this has a profoundly damaging effect on women readers" ( $p$. 40). In the beginning, the first novel Rita borrows from Frank is E.M. Forster's Howard's End. Her education begins and continues with male authors until the very end of the play, and this shows us Frank's tendency to associate literature with male authors as well as woman's need to become familiar with the male authority in the literary canon so that she can raise her voice later on.

Upon their discussion on "packing it in" Frank questions Rita why she has enrolled in if she is still in conflict about 
what she wants. Rita answers, "Because I wanna know" and upon being questioned about what she wants to know, she says she wants to know everything (Russell, 2001, p. 8). In this dialogue what is obvious is Rita's hunger for knowledge. In the patriarchal society, woman's hunger for knowledge is generally replaced by her maternal functions like bearing and rearing babies; therefore, she is not supposed to feed her own identity with literary or philosophical knowledge. Her socalled nature demands her to act as a womb which means she is doomed to be a tool for the male procreation, and her creative function is restricted to child-bearing. However, Rita does not want to be restricted to what is pre-determined for her; on the contrary, she dreams for freedom out of this imprisonment both as a working class member and a woman. Her wish for freedom becomes more obvious when she questions, "God, what's it like to be free?" (Russell, 2001, p. 9). Rita is not free as a working class woman, and she dreams about freedom that would enable her to find her own self. And the only possible way to have this independence she seeks is to change, and this change should come from inside.

Working as a hairdresser Rita observes woman's wish for physical change, and she becomes critical of this claiming that, "But these women, you see, they come to the hairdresser's cos they wanna be changed. But if you want to change y' have to do it from the inside, don't y'? Know like l'm doin" (Russell, 2001, p. 14). She sees the reality about woman's position, and she understands that the ultimate solution lies within an inner change for woman. When women come to the hairdresser's, they expect too much according to Rita because each wants to leave as a completely different person, however, the change in the hair or physical appearance does not bring any changes for woman's problem in the patriarchal society. That is why as a working class woman who is suffering not only because of being a woman in a masculine order but also because of her financial and cultural position in her class, Rita seeks her inner change through reading and eventually writing objectively so that she can raise her own voice within this male-dominated canon.

Rita is also a woman whose pre-determined destiny in the patriarchal structure dooms her to be a wife and a mother while her working-class background forces her to work outside the home in order to contribute to her family financially. Her position as a woman necessitates her to have a baby, however, although everyone expects her to do so, she says she does not want a baby yet. Thus, she deceives her husband saying that she has stopped taking pills although she has not. The explanation she gives in order not to have a baby shows that Rita's primary purpose is about herself and her position as a woman. She says, "See I don't wanna baby yet. See, I wanna discover meself first" (Russell, 2001, p. 15). As a woman, Rita's role has been pre-determined for her by patriarchy but she does not want to be subordinated by this fate, and she tries to change it via educating herself in an intellectual way. Through her reading and writing, Rita aims at discovering her lost self and voice as a woman under the masculine domination.

Rita's quest for her identity causes many problems in her relationship with her husband. In the beginning Rita tries to explain her husband what she is struggling for and why. However, all her attempts end up being in vain because when she says she wants "a better way of living her life", her husband answers, they might begin saving money in order to move to a new house in Formby (Russell, 2001, p. 16). Her reading and watching something different drives her husband mad since he cannot understand the real reason behind her discomfort. Her search for a new self does not mean anything for a man who thinks that they should have a baby now. Having a better house with babies is more than enough to make a woman happy from man's perspective, however, Rita cannot be satisfied with that, and she begins a discovery in order to seek her right to choose. However, while she is trying to obtain the right to choose, this process disturbs her husband Denny deeply that she cannot even study at home, and she has to write her essays at work. When she talks about Denny's reaction to her studies, she says, "It makes me stronger comin' here. That's what Denny's frightened of" (Russell, 2001, p. 36-37). Rita realizes that man is afraid of losing his pre-given power and authority in the patriarchal system if woman begins searching for her free self which cannot be controlled. This is actually what Denny feels about Rita's education. He is completely disturbed by her addiction to this education since he is aware that she is getting more conscious of her identity and directly more powerful.

Thus when Denny finds out that Rita is still taking pills not to have a baby; he gets completely mad and burns all her books and essays. Rita's more subjective purposes as a woman disturbs her husband extremely since she does not act properly according to the family structure in society. In "Women's Time" Julia Kristeva (1986) argues about woman's sacrifice in the patriarchal society and claims that the new generation of women has begun to revolt against this sacrifice. Kristeva asserts that, "The new generation of women is showing that its major social concern has become the symbolic contract as a sacrificial contract... And we consequently face a mass phenomenon - that they are forced to experience this sacrificial contract against their will" (p. 200). It is possible to mention Rita's name within this new generation of women Kristeva is alluding to since she is also in a struggle against this symbolic contract that forces women to sacrifice themselves in order to serve for the well-being of the other sex. Her rejection of having babies is obviously her first step that she takes towards obtaining a free self that is not based on the expected sacrifice. Rita's refusal to exist for others becomes obvious when she tells Frank how Denny has burnt all her books. She emphasizes how she is busy finding 
herself and that is why she cannot even have an affair with somebody else because having an affair means that she will forget about herself for the sake of him. While she is talking about her discovery inside, she focuses on her/self, and she says although this might sound selfish, the only thing she is interested in is what she has begun to find in herself (Russell, 2001, p. 39).

In her struggle to obtain her free self, Rita replaces her expected function as a woman to bear babies with her ambition to read and learn more in order to become an educated woman who can raise her voice against the socially constructed gender roles and woman's sacrifice. Focusing on Rita's choice of literature over having babies to fulfil her maternal function, it would be useful to refer to Julia Kristeva's (1986) argument about woman's choice of literature when she tries to answer the question of "Why literature?" as follows:

This identification with the potency of the imaginary is not only an identification, an imaginary potency, as a far too normative view of the social and symbolic relationship would have it. This identification also bears witness to women's desire to lift the weight of what is sacrificial in the social contract from their shoulders, to nourish our societies with a more flexible and free discourse, one able to name what has thus far never been an object of circulation in the community: the enigmas of the body, the dreams, secret joys, shames, hatreds of the second sex. (p. 207)

Kristeva (1986) asserts that a woman reader's identification with the imaginary world of literary texts stems from her wish to overcome the barriers that are set up in front of her. The social contract necessitates sacrifice for woman while man is allowed to fulfil his identity. Thus, Kristeva claims that this identification in literature presents new worlds for women in which they can define their bodies, pleasures, joys and hatreds at the same time (p. 207). Before enrolling in the Open University, Rita's devouring pulp fiction shows us her over-identification especially after she reveals that she has named herself after her favourite fiction writer. This can be analysed as her escape from the social contract that dooms her to self-sacrifice. She accepts that she has always had this feeling that she lacks something important in her life, however, each time she has tried to overcome this feeling via buying some new dresses. This is completely similar to what other women she is being critical of do when they try to change themselves at the hairdresser's. But now, after she decides to change herself inside, Rita says she has not been buying new dresses for twelve months, and she will not have one until she becomes acknowledged enough to pass an exam (Russell, 2001, p. 22).

Frank claims that Rita should learn objective criticism in order to succeed in her struggle, and he begins teaching her how to be objective in her criticism supported by references to "established literary critique" without including any sentiments (Russell, 2001, p. 22). But the important aspect of this process of getting educated by Frank is that Rita is absolutely absorbed in the male dominated literary canon reading male authors. Jill LeBihan (2001) also focuses on the lack of women writers in English departments in her article titled "Feminism and Literature" claiming that until the 1980s English literature departments at British Universities were extremely dominated by the works of the male authors. She continues to assert that even though a few female authors like George Eliot and Jane Austen were taught, this teaching had nothing to do with the feminist issues. Within this male authorized canon, feminists were generally dealing with the representations of women in the works written by men; these works, Jill claims, shaped the definition of woman "by representing women as sexual objects rather than politically powerful subjects"; thus "women receive a version of femininity and womanhood that is perpetually limited and therefore limiting" (p. 129). Also Rita's way towards a more critical self goes through her knowledge of literature dominated by men.

Discussing woman's reading, and the subject-object relationship between a text and its reader, Patrocinio P. Schweickart (1986) focuses on the immasculation of women via reading male-authored texts. Arguing whether the text manipulates the reader or the reader manipulates the text to make meaning, she highlights how the male texts affect the woman reader in her reading process. Eventually she asserts that, although some feminist critics believe that male texts have damaging effects on the woman reader, actually women themselves become the agents of their own immasculation via reading, and their autonomy in this process cannot be ignored. She questions what it means for a reader to take control of the reading experience:

Recall that a crucial feature of the process of immasculation is the woman reader's bifurcated response. She reads the text both as a man and as a woman. But in either case, the result is the same: she confirms her position as other. Taking control of the reading experience means reading the text as it was not meant to be read, in fact, reading it against itself. Specifically, one must identify the nature of the choices proffered by the text and, equally important, what the text precludes - namely, the possibility of reading as a woman without putting one's self in the position of the other, of reading so as to affirm womanhood as another, equally valid, paradigm of human existence. (p. 50)

From this perspective, even the feminist critics cannot avoid reading androcentric works because literature in the patriarchal structure is dominated by the male authors. Therefore, Schweickart (1986) asserts, by the time a woman becomes a feminist critic, she has already read various androcentric works. Throughout this process of the female 
inclusion within the male literary canon, the woman reader becomes immasculated. However, as Schweickart emphasizes, it is not possible to think of women as mere victims of patriarchy in this process; on the other hand, it is unavoidable that women end up being the agents of their own immasculation via their attempts to pave their way into the male dominated literary canon. When the woman reader reads male texts, as stated above, she reads both as a man and as a woman. In both cases, either when she reads as a man or as a woman, she has the same consequence of approving her position as the other. However, what she actually needs to succeed within this process of reading is to assert herself as an autonomous another that exists with her own worth and values. For Schweickart, this is possible by means of reading the text against itself focusing on what it includes as well as what it excludes (p. 50). In Rita's case, her immasculation begins at the moment when she prefers reading and educating herself into a more philosophical way of life instead of having babies as a proper wife. Her devouring pulp fiction in a feminine manner is shifted towards a more male reading of male texts under the guidance of Frank who provides her with the major texts of the male authors. However, the fact that Rita chooses to read also as a man does not only mean that she completely ignores her femininity in order to be absorbed in the male literary canon; on the contrary, this is the way she chooses in order to assert her own identity that is as valid as the male one.

On the other hand, while Rita is trying to educate herself in order to seek for a female self that is not predetermined by the patriarchal structure; she also tries to find the meaning of life which the working class people are devoid of. Thus it would not be enough to assert that the barriers in front of her that prevent her discovery of self are established by the subordination of woman. As well as being a woman in the masculine order, Rita also comes from a working class background which makes her conditions even more difficult compared to other women in the upper class. Thus her fight is not only against patriarchy but also against the working class life that is devoid of a meaning and a proper culture. Beginning with her desire to go to school as a child, the shallow perspective of her mates and her family that "school could be anythin' other than useless" turns out to be a clear example of the lifestyle she has been forced to adopt within the environment she has grown up (Russell, 2001, p. 21). After she decides to educate herself in order to free her restricted identity both as a woman and a working class member, her first criticism about E.M. Forster's Howards End that she considers as crap stems from her subjective dislike with the author who says, "We are not concerned with the poor" (Russell, 2001, p. 23). Here Frank indicates that she is being completely subjective with this approach, and if she wants to be an objective critic, she has to learn to analyse the texts from an objective point of view. During this process, Frank emphasizes that "Devouring pulp fiction is not being well read" and he tells her she needs to be more selective while reading (Russell, 2001, p. 30). However, for a long time until the very end of the play, Frank is the one who chooses what to read for Rita, and, as has already been stated, what he chooses is always a male-authored text.

During the process of education, Rita also fights against the meaninglessness of the working class life she has been pursuing. Thus, she is not only struggling against the subordination of woman but also against her social background. In her discussion of patriarchy Sheila Rowbotham (2006) refers to the working class women who lack the opportunities the upper class women have. She claims that:

It has often been said that as women we have come to know that the personal is 'political' because we have been isolated in the personal sphere. I think this is only half the story. We were isolated in the personal sphere, but some of us were hurtled dramatically out of it by the expansion of education and the growth of administrative and welfare work, and while some (working-class and black women) were never so luxuriously confined. (p. 55)

Although the restriction of woman within the male-dominated culture cannot be ignored, the differences among women themselves should not be disregarded, either. So, while considering Rita's case and her struggle to search for her free self, it is clearly not enough to analyse her position only as a woman without referring to her social background. As Rowbotham points out above, the circumstances of the working class women differ from the others who have at least the comfort and luxury of their financial status.

Thus, Rita does not only search for a free female self but she also tries to find the meaning of life which the working class people lack. When she talks about Peer Gynt to one of the women at the hairdresser's, the woman thinks it is a new perm lotion. However, when Rita tells about the play, they woman says, "I wish I could go off searchin' for the meanin' of life" (Russell, 2001, p. 35). Contemplating about this wish, Rita asserts that although the working class people seem to be content with what they have, they are actually not deep inside because there is no meaning in their life. Despite of their better positions compared to the past, she claims, "there's like this sort of disease, but no one mentions it" (Russell, 2001, p. 36). There is a disease in this part of society, but nobody dares to mention or do something about it; therefore, Rita appears to be the courageous one as a woman who can dare to stand against both the disadvantages of being a woman in the patriarchal system and a working class member in a capitalist society. She ceases to pretend any more as others do, she understands the reality behind what is visible especially when she sees her mother who begins 
crying just after she sings in the pub claiming that they could actually sing better songs.

Rita's entire attempt is to sing better songs through her education in literature and philosophy. She does not want to join the dinner at Frank's house because she does not want to be mocked as a silly woman who tries to learn. She wants to become as serious as those educated men and women from the upper class so that she can raise her voice among them in order to be heard, and she works hard for this purpose. When Frank claims it is enough for her to be herself, she answers, "I don't want to be myself. Me? What's me?" (Russell, 2001, p. 52). Both as a subordinated woman and a working class member, she is devoid of the meaning of life as well as an independent self that can enable her to make individual decisions. Nevertheless, she cannot keep her silence against this fate, and she makes her first important decision not to go on living as emptily as she has been doing until she is twenty-six. Although her husband Denny claims hers is not the age to get educated, she insists on her own decision.

Considering Rita's insistence not to conform to her pre-determined fate, it is possible to conclude that she does not accept to be the tool of her own victimization as a woman. In "Feminism and History" Judith M. Bennett (2006) indicates that:

Women have a large part to play in this historical study of patriarchy, not merely as victims, but also as agents. Women's support has always been crucial to the endurance of patriarchy; hence, we must examine and understand the motivations of women who have colluded in their own oppression. (p. 67)

The belief that women are fragile beings and the pre-determined space is the safest one for them which protects them from the dangers outside has been imposed on women who have ended up admitting their subordination for the sake of safety instead of dangerous freedom. However, in Rita's case, she makes her most important decision when she has to choose between her education and her matrimonial life. One day she comes home to find her case packed by her husband who forces her to choose. Eventually Rita makes her choice of education to have her independent self sacrificing her family life. That means Rita rejects to be the agent of her own victimization under the masculine order. Denny's fear that Rita gets more powerful as she attends the courses with Frank is eventually realized when Rita makes this important decision leaving her so-called safe home for the dangerous outer world without being afraid of her vulnerability.

In the beginning of Act II when Rita is back from the summer school in London, she is in a new, second-hand dress. This dress on her shows the change she has been through as a result of her reading and writing. Especially after the summer school, Rita appears to be a woman who can contemplate and talk about important works of art in an objective and critical way. Even her new house and her flatmate Trish appear to be the symbols of the big change in her life; she has a room now full of plants and books like Frank's office. She even attempts to alter her voice in order to talk properly. On the one hand, as Rita changes towards Frank's lifestyle as well as thinking style; on the other hand, Frank begins to change towards Rita's old way of acting and thinking. While Rita can understand the difference between pulp fiction and serious literature now, Frank begins to think that Rubyfruit Jungle is an excellent book. This shift in the roles of Frank and Rita becomes obvious when Rita sits "in the armchair by the window, reading a heavy tome" and Frank "enters carrying his briefcase" (Russell, 2001, p. 68). Clearly the roles are shifted between Frank and Rita, and eventually each becomes a teacher for the other. While Frank teaches Rita how to be an objective and critical reader, Rita teaches Frank how to be more sentimental and subjective judging the education system. Hence, Frank concludes that he wants to change his name to Mary Shelley; in a way, he compares himself to Frankenstein who creates a monster. Frankenstein is also very enthusiastic with what he intends to create in the beginning, however, upon seeing the monster that is born, he runs away not to see him again. He cannot even dare to look at his own creature. In Frank's case, as he helps Rita change in the way she wants, he himself changes, and consequently he cannot tolerate seeing Rita in her new existence that is dependent on nobody.

As a result of her education process Rita fulfils her search for an independent self in order to make her own choices. Discussing the self-less existence of woman under the domination of patriarchy Sandra M. Gilbert and Susan Gubar (2000) point out that:

Whether she becomes an objet d'art or a saint, however, it is the surrender of her self - of her personal comfort, her personal desires, or both - that is the beautiful angel-woman's key act, while it is precisely this sacrifice which dooms her both to death and to heaven. For to be selfless is not only to be noble, it is to be dead. A life that has no story is really a life of death, a death-in-life. The ideal of "contemplative purity" evokes, finally, both heaven and the grave. ( $p$. 25)

Obeying the patriarchal structure that confines woman to the domestic sphere asserting that the outer world threatens her safety, woman sacrifices her identity. Eventually if she chooses to be protected, she does it at the cost of her independent self; thus, she becomes selfless and dependent. All her desires and pleasures are sacrificed for the 
male protection, however, this safety dooms her to a passive and repetitive lifestyle which lacks a philosophical and critical approach to life. As Gilbert and Gubar also point out, this sacrifice causes her to die while she is still alive because this lifestyle does not allow her to be actively creative. Within these circumstances Rita seeks for a rebirth which she believes she might have via education. As a result, she is capable of claiming her free self in order to choose for herself without being dependent on either a husband or a teacher. At this moment, she gets furious with Frank because he also tries to shape her according to his own ideas, and he cannot tolerate her thinking differently. She does not want to be dependent on anybody, what she would like to do is to make her own reasonable decisions without being bound to anybody else. As Frank goes on calling her Rita, she announces that there is nobody left who calls her Rita any more. Frank's reaction to this is whether she has changed it to Virginia, or Charlotte, or Jane, or Emily (Russell, 2001, p. 79). For the first time in the play, Frank utters the names of famous women writers in British literature, and this gives hope about Rita's future as a woman writer.

The most important aspect of Rita's change is that now she can choose what she wants to do. In the end of the play she emphasizes the importance of this difference saying, "I dunno. I might go to France. I might go to my mother's. I might even have a baby. I dunno. I'll make a decision, I'll choose. I dunno" (Russell, 2001, p. 83). Then she puts on the new dress Frank has bought for him, and this is a dress an educated woman would have. In her new mood and new appearance, Rita's life completely changes. She has so many options, and obviously she is happy to have the luxury to choose without obeying the pre-determined decisions for her. Now, she might even have a baby because it would be her own wish not somebody else's. Consequently, Rita's cutting Frank's hair in the last scene of the play can be regarded as man's emasculation by woman's creativity. Frank who has represented the male dominated philosophy and literature throughout the story is eventually emasculated by a woman who is able to raise her voice after getting familiar with the dominant male voice in literature.

The early discussion in this paper about the Cartesian dualism between the mind and body each represented by each sex ultimately results in woman's subordination as the lacking other who does not have the potential to think critically. However, this so-called defection of woman is actually not natural but constructed by patriarchy in order to serve man. The woman whose voice has been silenced by the male domination in literature first needs to have a familiarity with this male-dominated literature in order to raise her own voice as an objective and critical reader and writer. This is what Rita experiences during her education studying the male authored texts chosen by Frank, however, eventually she causes Frank to utter the names of women writers which shows a hopeful sign for Rita's future as a reader and writer. In the end, when she cuts Frank's hair, she also proves her power over him via attempting to give him a new appearance. Thus, the woman that has represented the body on which man's mind operates claims her own self not only as a passive body but also as a creative intellect. Consequently, the muted woman is able to raise her voice by claiming her own independent identity.

\section{References}

Bennett, J. M. (2006). Feminism and history. In Morgan, S. (Ed.), The feminist history reader (59-73). London: Routledge.

Bleich, D. (1986). Gender interests in reading and language. In Flynn, E., \& A., Schweickart, P. P. (Eds.), Gender and reading: Essays on readers, texts, and contexts (234-266). London: John Hopkins University Press.

Butler, J. (2006). Gender trouble. London: Routledge.

Crawford, M., \& Chaffin, R. (1986). The reader's construction of meaning: Cognitive research on gender and comprehension. In Flynn, E., \& A., Schweickart, P. P. (Eds.), Gender and reading: Essays on readers, texts, and contexts (3-30). London: John Hopkins University Press.

Gilbert, S. M., \& Gubar, S. (2000). The madwoman in the attic: The woman writer and the nineteenth-century literary imagination. London: Yale University Press.

Kristeva, J. (1986). Women's time. In Moi, T. (Ed.), The Kristeva reader (187-213). New York: Columbia University Press.

LeBihan, J. (2001). Feminism and literature. In Gamble, S. (Ed.), The routledge companion to feminism and postfeminism (129-139). London: Routledge.

Littau, K. (2006). Theories of reading: Books, bodies and bibliomania. Cambridge: Polity Press.

Moi, T. (1999). What is a woman? Oxford: Oxford University Press.

Rowbotham, S. (2006). The trouble with patriarchy. In Morgan, S. (Ed.), The feminist history reader (51-56). London: Routledge.

Russell, W. (2001). Educating Rita. London: Methuen Drama.

Schweickart, P. P. Reading ourselves: Toward a feminist theory of reading. In Flynn, E., \& A., Schweickart, P. P. (Eds.), Gender and reading: Essays on readers, texts, and contexts (31-63). London: John Hopkins University Press. 
ISSN 2239-978X

ISSN 2240-0524
Journal of Educational and Social Research MCSER Publishing, Rome-Italy
Vol. 5 No.1 S1 April 2015 